\title{
Читалачки клуб за особе са интелектуалним тешкоћама
}

\author{
Горан Траиловић \\ Градска библиотека Панчево \\ goran@biblioteka-pancevo.org.rs
}

\begin{abstract}
Сажетак

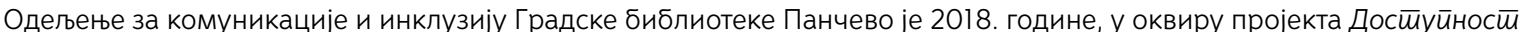

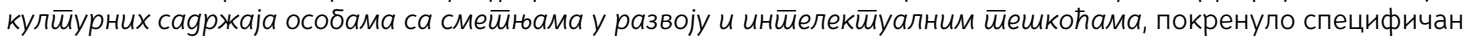
Читалачки клуб који је окупио двадесетак младих особа. Активности Клуба су реализоване у партнерству са Центром за културу и екологију ПанАрт и Удружењем „На пола пута", а његов рад је пратио и усмеравао стручни тим састављен од дефектолога, педагога, психолога и библиотекара.

У раду се износе почетне замисли и очекивања аутора пројекта - писца овог текста, припреме организатора, реализоване активности и евалуација, као и разлози због којих није настављен наредне године. Писан је на основу увида у рад Клуба, непосредног учествовања у активностима, текстуалне и видео-документације која се чува на Одељењу за комуникације и инклузију панчевачке Библиотеке. Посебно су истакнути реакције и мишљења његових чланова који се односе на реализоване активности. Најатрактивнији резултат деловања Клуба је кратки играни филм Љубав у библиотеии, чији су протагонисти његови чланови, који су сами осмислили и сценарио. На основу резултата испитивања учесника и сарадника укључених у пројекат и личног увида аутора, може се закључити да је он успешно реализован.
\end{abstract}

Кључне речи: Читалачки клуб, доступност културних садржаја, особе са сметњама у развоју, особе са интелектуалним тешкоћама, перцепција књижевног текста, Градска библиотека Панчево, Одељење за комуникацију и инклузију, Центар за културу и екологију ПанАрт, Удружење „На пола пута", Друштво за помоћ ментално недовољно развијеним особама, стручни сарадници, „индивидуална карта читаоца“

\section{Увод}

Читалачки клубови су традиционална и добро позната форма рада усмерена на подстицање читања. Библиотеке их и данас успешно организују, ${ }^{1}$ али као да остају у сенци различитих радионица и манифестација, па нису довољно „видљиви“ широј јавности. ${ }^{2}$ Овај прилог је посвећен Клубу који је деловао у Градској библиотеци Панчево (ГБП) током 2018. и окупљао младе са тешкоћама у читању. Њихов рад је пратио и пружао им подршку стручни тим, ${ }^{3}$ а у раду је било ангажовано више асистената, писаца, глумаца, библиотекара и техничких лица, као и сниматељ и редитељ Владимир Кајловиц из ПанАрта, ${ }^{4}$ партнера на пројекту. Рад Клуба

\footnotetext{
1 Попут Градске библиотеке у Новом Саду - Градска библиотека у Новом Саду, преузето 12. 5. 2020, https://www.gbns.rs/index.php?option=com_content\&view=article\&id=974:04102019-citalacki-klub\&catid=40\&ltemid=205; Библиотеке "Свети Сава“ у Земуну - Библиотека града Београда, „Читалачки клуб 'Читања и одговори'“, преузето 20. 5. 2020, https://www.bgb.rs/index. php/zemun/1259-2018-04-20-10-12-10; библиотеке у Бачкој Паланци - Народна библиотека „Вељко Петровић“ Бачка Паланка, "Читалачки клуб“, преузето 20. 5. 2020, http://www.bibliotekabackapalanka.com/index.php/dogadjanja/vesti/923-klub; Градске "књижнице и читаонице Пула - Gradska knjižnica i čitaonica Pula, „Klub ljubitelja čitanja KLjuČ, preuzeto 20. 5. 2020, https:// gkc-pula.hr/hr/proba-broj-cetiri/k/ итд.

2 На основу резултата претраге веб-страница библиотека, организација, друштвених мрежа, као и претраживањем по кључној речи на Гуглу, уочљиво је да су много видљивији школски и виртуелни књижевни клубови.

3 Стручни тим су чинили: Александра Јанић, дипломирани педагог и лиценцирани радник у социјалној заштити за опште послове, Биљана Милошевић, здравствени сарадник дипл. дефектолог логопед, психолози Наташа Милојевић (која је и водила већи бро) састанака) и Тамара Тодоровић, као и библиотекар саветник, координатор и аутор пројекта Горан Траиловић.

${ }^{4}$ Центар за културу и екологију ПанАрт, http://panart.virtuelnopancevo.rs/.
} 
читалаца ГБП подржале су и две панчевачке организације цивилног сектора, „На пола пута“" и Друштво за помоћ ментално недовољно развијеним особама (МНРО). ${ }^{6}$ Министарство културе и информисања Републике Србије и Градска управа Панчева финансирали су трошкове

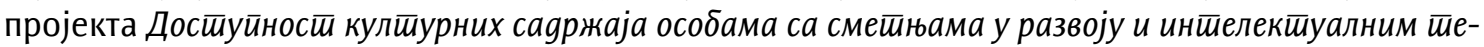
шкоћама у оквиру кога је реализован овај клуб. ${ }^{7}$

\section{Читалачки клуб за особе са сметњама у развоју и интелектуалним тешкоћама - полазне претпоставке}

Иако је Градска библиотека Панчево од оснивања имала бројне и разноврсне програме, окупљала људе од пера и љубитеље лепе речи, у архивској грађи и објављеним изворима о њеном раду нема помена о организовању читалачких клубова. Крајем педесетих година прошлог века, када се убрзано развија и модернизује, постојао је извесно време Клуб љубитеља књиге, ${ }^{8}$ а Дечија библиотека ГБП имала је своју литерарну секцију. ${ }^{9}$ У оквиру редакције часописа Библи, сарадницима из панчевачких основних школа пружана је помоћ приликом писања прилога за њихов лист, ${ }^{10}$ а Регионални центар за таленте „Михајло Пупин“ је протеклих година у Библиотеци повремено одржавао креативну радионицу за писање књижевних текстова. Beћ дуже време на Дечјем одељењу, једанпут недељено, одржава се причаоница за предшколце. ${ }^{11}$ Иако на неки начин блиске форми читалачког клуба, све набројане активности се од ње разликују у битним сегментима. Један од првих задатака Одељења за комуникације и инклузију ГБП био је оснивање читалачког клуба 2018. и то за специфичну категорију корисника - за младе са тешкоћама у читању и перцепцију књижевног текста. ${ }^{12}$

Читалачки клуб панчевачке Библиотеке је, колико је познато, једини те врсте у Србији, специфичан управо због популације којој је намењен. ${ }^{13}$ Пројекат се односио, првенствено,

5 Удружење „На пола пута“, http://www.napolaputa.org/.

6 Друштво за помоћ ментално недовољно развијеним особама (МНPO), http://savezmnrosrbije.rs/o-nama/lokalna-udruzenja/; https://www.facebook.com/Udruzenje-MNRO-Dragulji-Pancevo-182504195461857/.

${ }^{7}$ Средства су добијена на редовном годишњем Конкурсу Министарства културе и информисања за финансирање или суфинансирање пројеката из области савременог стваралаштва у Републици Србији у 2018. години (област културних делатности особа са инвалидитетом) и Јавном конкурсу за су/финансирање пројеката у области културе за 2018. годину (област деловања остала извођења културних програма и културних садржаја), који је расписала Градска управа, Секретаријат за јавне службе и социјална питања. Формални носилац пројекта је био Центар за културу и екологију ПанАрт, Панчево.

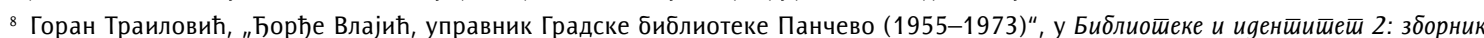
раgова са научної скуйа оgржаної 24. и 25. маја 2019. іоgине у Паниеву, главни уредник Гордана Стокић Симончић, одговорни уредник Горан Траиловић (Панчево: Градска библиотека, 2019), 96-106.

9 Градска библиотека Панчево, Архива, „Дечија библиотека је отворена 1. маја 1956.", Допис управника ГБП, Ђорђа Влајића Народном одбору општине Панчево, Одељењу за просвету и културу, бр. 397, од 20. 12. 1957.

10 Библи (Бачке ошикачене новине) покренуте су 2002. године. Редакцију су чинили ученици панчевачких основних школа, а уредник је био Милован Лукић, књижничар Градске библиотеке Панчево.

11 Причаоницу „Читам ти причу“ води библиотекарка Милана Гаврилов.

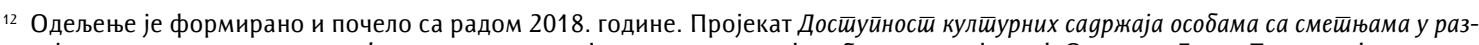

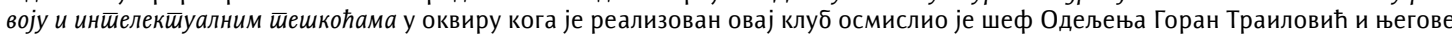
активности су биле део годишњега плана рада Одељења и ГБП. Идеја је била и да се сензибилишу стручни радници у Библиотеци и да колеге са других одељења евентуално узму учешће у његовом раду, што је остварено тек у мањој мери.

13 Чак ни расположиви извори и литература са наших простора које је аутор могао да консултује нису обимни: Кnjižnice grada Zagreba, Čitalački klub, „Mojih sat vremena čitanja' u Knjižnici Savski gaj (Zagreb)“, preuzeto 15. 3. 2020, http://www.kgz.hr/hr/

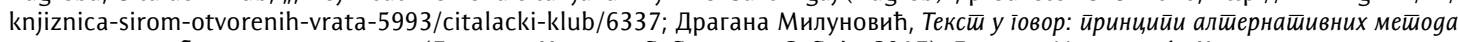

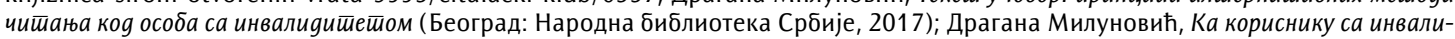

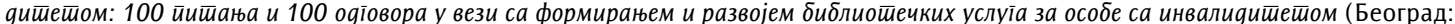
Народна библиотека Србије, 2012); Dragana Milunović, Biblioteke za hendikepirane (Beograd: Zadužbina Andrejević, 2006); Kortni Dejns-Džouns, prir., Unapređivanje bibliotečkih usluga za osobe s invaliditetom (Improving Library Services to People with Disabilities), prevela Dragana Milunović (Beograd: Narodna biblioteka Srbije, 2009), Драгана Милуновић, „Хендикепирана деца као корисници

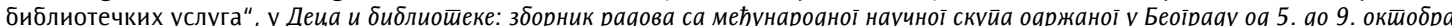
2005 (Београд: Филолошки факултет Универзитета; Библиотекарско друштво Србије, 2006), 501-507; Биљана Данић Грбић, „Улога библиотека као агенса социјализације деце и омладине са посебним потребама“, у Деца и библиошеке: зборник раgова..., 655-665. Сродних програма, попут оног који се помиње у последњем тексту било је још мање. 
на књижевно стваралаштво, а идеја његовог аутора била је да се особама са сметњама у развоју и интелектуалним тешкоћама на најоптималнији начин приближе ови садржаји. Његова реализација захтевала је мултидисциплинарни приступ и ангажовање стручњака различитих профила: од посредника између писаног текста (драмских уметника, писаца...) и ових младих људи, преко личних асистената, до дефектолога, педагога и психолога. Циљ је био да се особама са сметњама у развоју и интелектуалним тешкоћама омогући да читање доживе као пријатну активност и развију љубав према књизи. ${ }^{14}$ То је требало да допринесе превладавању значајних ограничења у њиховом животу који, по правилу, карактерише смањен ниво адаптивних вештина попут комуникације, социјалних вештина, самоусмеравања и др. Трајна добробит била би стицање нових сазнања, стварање сигурнијих „мапа“ и „координата“ света око њих, јачање осећаја сигурности и квалитетна испуњеност слободног времена. Идејни аутор је веровао да би програм могао да има утицаја и на евентуални радни ангажман ових младих људи. Будући да они често имају проблеме приликом стварања социјалних односа са вршњацима и околином, читање и дружење са књигом би представљало велику животну радост и одређену компензацију за мањак социјалних контаката и егзистенцијалну отуђеност.

Иако је, начелно, Читалачки клуб био отворен за све заинтересоване, организатор је проценио да је најупутније да се обрати удружењима грађана и установама у граду које окупљају и брину о особама којима је намењен. ${ }^{15}$ Предочена им је идеја пројекта и замољене су да анкетирају своје кориснике, млађе од 30 година, да ли би учествовали у његовим активностима. Одлучено је да се условно постави ова старосна граница како би се добила коликотолико хомогена група, а сматрало се да је ова групација спремнија да прихвати планиране активности.

Ментални и интелектуални капацитети особа са сметњама у развоју и интелектуалним тешкоћама разликују се битно од оних код њихових вршњака те су активности пројекта биле брижљиво конципиране. Организатори су планирали да, по формирању групе, прво одреде штиво које ће обрађивати на окупљањима и открију књижевна дела која ће код чланова подстаћи „задовољство у тексту“, а њихово присуствовање и ангажман на састанцима Клуба бити жељена и пријатна активност. То би урадили у консултацији са одговарајућим стручњацима и евентуално би се одлуке кориговале током трајања пројекта, са могућношћу поделе групе у зависности од тока пројекта и реакције учесника. Осим групног, предвиђени су и индивидуални рад и разговори учесника са одговарајућим стручњацима како би се дошло до неке врсте „индивидуалне карте читаоца“ која би пружила увид у могућности и ограничења чланова за примање књижевних информација, естетских и других порука. Подаци би помогли у кориговању и даљем усмеравању тока пројектних активности.

Прва фаза пројекта односила се на решавање организационих питања и консултације са партнерима, њихово информисање и обавештавање потенцијалних учесника, њихових родитеља односно старалаца - што би водило формирању почетне групе. Изабран је један двосатни

\footnotetext{
14 Детаљан опис пројекта се, заједно са свим другим документима чува у архиви пројекта и Читалачког клуба на Одељењу за комуникације и инклузију ГБП.

15 Реч је о организацијама цивилног сектора: „На пола пута“, Друштво за помоћ ментално недовољно развијеним особам (МНРО), „Велики мали“ - иницијатива за инклузију, ЖМИГ и др. Рачунало се и на стручњаке из Школе за основно и средње образовање "Мара Мандић“, Панчево. Процењено је да та удружења окупљају најмање стотинак активних чланова од интереса за овај пројекат (не рачунајући стручњаке који воде удружења и одређене активности у њима и волонтере).

Позитивна искуства Књижнице и читаонице „Фран Галовић“ Копривница (и негативна искуства неких других библиотека) говоре да би пројекте који се тичу припадника рањиве популације требало реализовати у партнерству са одговарајућим локалним удружењеима и организацијама. - Dijana Sabolović-Krajina, Ljiljana Vugrinec i Danijela Petrić, „Knjižnična usluga za slijepe i slabovidne u Knjižnici i čitaonici 'Fran Galović' Koprivnica: od projekta do implementacije“, Vjesnik bibliotekara Hrvatske God 53, br. 2 (2010): $76-92$.
} 
термин недељно, ${ }^{16}$ не рачунајући индивидуални рад приликом прве процене и даљег периодичног индивидуалног рада и разговора са члановима групе.

Аутор пројекта је сматрао да би изабрано штиво, на почетку, било добро да тумаче „посредници“, драмски уметници, а затим и писци који имају сензибилитет у раду са осетљивом популацијом. Њихово ангажовање би допринело интерактивности књижевних сусрета, провоцирању пажње и реакција присутних. Циљ је био да се још у овој фази подстакне разговор о изабраном штиву, односно темама које оно нуди и да чланови групе постану активни учесници у пројекту. О броју и обиму књижевних дела која ће бити представљена одлучивано је током реализације пројекта, у зависности од његовог тока и реакције припадника групе. Акценат није био на бројности и обиму (квантитету), већ на томе да свако открије „своју књигу", текст који воли да чује и прочита. Буџетом пројекта је предвиђено да омиљена књига буде поклоњена сваком припаднику групе. До летње паузе свако је требало да стекне „своју књигу“ са којом ће се дружити током лета и коју ће представити другима на јесењем окупљању. ${ }^{17}$

Индивидуални рад и процена требало је да открију које су могућности и индивидуална ограничења чланова Клуба (делимична писменост, слабији вид, поремећај пажње, аутизам...) и да ли их је и на који начин могуће превладати (писмо, слог, формат, начин интерпретације, „тежина“ штива...). Организатор пројекта је планирао да део ових активности претходи првом окупљању, а да затим упоредо теку редовни састанци и активности логопеда, дефектолога, психолога, по потреби неуропсихијатара и других специјалиста који би били значајна подршка пројекту. ${ }^{18}$

У следећој фази би спољне „посреднике“ између текста и припадника групе замењивали сами учесници за које се процени да су спремни да преузму улогу „посредника“, а који би имали потребну асистенцију личних асистената и стручних сарадника. До краја пројекта требало је да свако, макар у ограниченом обиму, преузме ову улогу.

Организатор је предвидео да се током пројекта оствари синестезични приступ и реализују различити драмски, филмски, музички и ликовни програми, или одлазак на изложбе, концерте, позоришне представе и филмске пројекције. Намера је била да се путем тих програма чланови Клуба „преведу“ из позиције (пасивне) публике у активне ствараоце у одређеним областима, па и да се креира краћа драмска представа, филм, концерт или изложба. Сматрало се да ће то иницирати буђење њихове креативне енергије и можда резултирати оригиналним ауторским делима.

Текућа евалуација би омогућила корекције „у ходу“, а завршном, на крају године, организатор би сагледао све битне елементе пројекта, поставио могући модел оваквог клуба и донео потребне закључке и смернице за наставак рада у наредној години. Одређена форма извештаја и анализе пројекта би била јавно доступна (и теоријски размотрена у стручној периодици). Модел би могао да буде драгоцен другима који би желели да покрену сличне активности. Установљен Читалачки клуб би наставио са радом у оквиру Библиотеке.

Пројекат је предвиђао ангажовање великог броја стручњака за релативно мали број особа којима је био намењен и које ће бити укључене као корисници (до 1000 у локалној средини, од којих би реално могао да буде ангажован само десети део), али је циљна популација много већа. Резултати овог програма могу бити од великог значаја за све особе са интелектуалним

16 Увек у истом дану и у исто време, уторком од 18 до 20 часова у малој читаоници на Дечјем одељењу, с тим да је састанак групе "званично“ трајао око 60 минута, а преостало време било посвећено индивидуалним активностима чланова Клуба и „неформалном“ дружењу, у зависности од њиховог слободног времена и интересовања.

17 Усмено или на други начин који буде најпогоднији за њих (дневник читаоца, ликовна мапа и сл.).

18 Показало се да су специјалисти окупљени у стручном тиму били више него довољна подршка пројекту, тако да није било потребе за ангажовањем нових спољних сарадника. Стручњаци су бирани на основу њихових компетенција, ранијих контаката и добре сарадње коју су организатори имали са њима. 
тешкоћама у земљи и региону. Без обзира што оне чине само 2,5\% грађана, ${ }^{19}$ библиотеке су, својом мисијом и домаћим и међународним актима, у обавези да развијају потребне сервисе и за њих. ${ }^{20}$

Аутори су сматрали да би, пошто се пројекат реализује у Библиотеци, он неминовно обухватио и један број библиотекара који би стекли нова знања и компетенције у раду са младима са интелектуалним тешкоћама и сензибилисао цео колектив. То би водило даљем развоју нових сервиса за онај део грађана који из различитих разлога не могу (или на отежан начин могу) да користе услуге библиотеке. С обзиром на чињеницу да је у српским библиотекама мало библиотерапеутских програма, овакав пројекат би могао да допринесе њиховом развоју и то на потпуно новим основама од постојећих и теоријски утемељних модела у текућој библиотекарској стручној литератури. Такође, идеја је била и успостављање сарадње са библиотекама, разним асоцијацијама и другим партнерима у земљи и иностранству који се баве активностима намењеним особама са интелектуалним тешкоћама.

\section{Испитивање функције читања}

Маја месеца 2018. организатори из Библиотеке су обавили договоре са партнерима у пројекту, а „На пола пута“ испитало да ли су корисници овог удружења заинтересовани за учешће у њему. ${ }^{21}$ Забележени су одговори испитаника на постављена питања и то су били први подаци за „картоне читалаца“. Испоставило се да неки од њих читају и воле поезију, Вука Караџића и Иву Андрића, трилере, љубавне романе... купују књиге и чланови су Библиотеке, поједини баш и не читају, некима други читају, док њих неколико пише поезију. Већини се идеја допала ( „Супер ми је идеја за клуб“; „Драго му што ће упознати писце као што сам ја“...), а имали су и одређена питања и недоумице на које им је одговорено („Морам да знам колико тамо морам да будем, ко ће ићи са нама, ко ће нам помагати кад тај човек буде причао кад ја не разумем све“; "Где је то што идемо?“; „Кол “ко се то плаћа, та библиотека и где је то. Како то ради? Моја сестра у Београду плаћа то, неће књигу да ти дају џаба, каже мама“...).

Пре првог окупљања, урађено је „испитивање функције читања“ девет заинтересованих корисника и дат „Извештај о извршеној процени способности читања“ координатору програма.

\footnotetext{
19 Истраживања у свету су показала да је број особа са сметњама у развоју и интелектуалним тешкоћама у укупној популацији до 2,5\%. - Видети нпр. Božidar Nikša Tarabić і Patricia Tomac, "Intelektualne teškoće - dijagnostika i klasifikacija“, Gyrus 3 (2014): 131. Према томе, у граду од око 100.000 становника могло би да живи њих 2500. Процењено је да број едукатибилних особа прелази 1000 у Панчеву, а тај број би морао бити дупло мањи када се узму у обзир они до 30 година (којима је пројекат намењен). Процењена бројност није могла бити проверена и она је оквирно прихваћена, а била је од секундарног значаја за пројекат који је могао да окупи само мањи број заинтересованих. Како је ово први читалачки клуб у панчевачкој Библиотеци намењен специфичној популацији и својеврстан експеримент, планирано је да почетна група буде мања. Организатори су сматрали да са већом групом рад не би ни био могућ због специфичности пројекта (а и сваки други рад са већом групом је тешко изводљив). Планирано је да се по потреби формира више група.

${ }_{20}$ Види: IFLA/UNESCO, Манифести за јавне библиошеке, преузето 14. 8. 2019, https://www.ifla.org/files/assets/public-libraries/publications/PL-manifesto/pl-manifesto-sr.pdf; Међународна федерација библиотекарских удружења и институција IFLA, UNE-

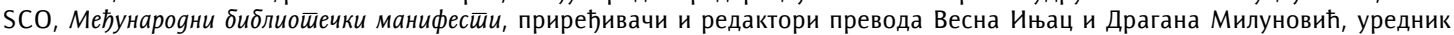
Весна Црногорац (Београд: Библиотекарско друштво Србије, 2014), доступно и на: http://nub.rs/fileadmin/dokumenti/ostali_dokumenti/Medjunarodni-bibliotecki-manifesti.pdf итд.

21 Стручни сарадници овог удружења су својим корисницима објаснили идеју пројекта, распоред активности, обавезе и предности учешћа, питали их коју књигу су последњу прочитали, која им је омиљена и да ли знају њен наслов и аутора, да ли сами читају или им неко помаже (и ко), да ли имају своју личну библиотеку, да ли знају где је Библиотека и да ли су њени чланови и утврдили ко жели да учествује у пројекту. Крајем маја и почетком јуна обављена су два групна интервјуа и само се пет корисника изјаснило да неће учествовати у пројекту због заузетости или здравственог стања (само је једна особа образложила да то „не воли“). У првом тренутку испитано је 18 корисника у групном разговору у трајању од један сат. Неиспитане кориснике сарадници су накнадно контактирали телефоном или су обавили индивидуални разговор са њима. Касније се Клубу придружио један штићеник Друштва за помоћ ментално недовољно развијеним особама, а било је планова за формирање још једне групе односно клуба који би обухватио више чланова овог Друштва. У раду Клуба је учествовало двадесетак младих особа (углавном између 14 и 30 година), од чега више од половине није пропустило готово ниједно окупљање. На једном састанку је било само пет чланова, на више по седам, а углавном по 12 „читалаца“. Одржано је двадесетак „званичних“ окупљања чланова Клуба и већи број „незваничних“, као што су одласци на изложбе, позоришне представе и Сајам књига у Београду.
} 
У њему се наводи да су за „инструменте процене функције читања изабрани Тест читања базиран на тежини текста и Тродимензионални тест читања“. ${ }^{2}$

Циљеви тестирања су били:

1. утврђивање могућности и ограничења особе у примању/разумевању књижевних информација и других естетских порука,

2. утврђивање начина читања,

3. врсте ограничења, као и

4. израда дела „индивидуалне карте читања“ у којој би добијени образац функције читања био искоришћен као полазна база за утврђивање начина превазилажења тешкоће или одабира одговарајуће компензације. ${ }^{23}$

Способност читања и разумевања прочитаног (оба писма, ћирилица и латиница) утврђена је код пет и делимично код два испитаника. Могућност препознавања графема, читање речи и аутоматских секвенци није присутна код два испитаника.

У контексту индивидуалне вербалне комуникације, сви испитаници су испољили висок степен сарадње. Они су изјавили да воле уметност, заједничко гледање филмова, серија, воле музику. Закључено је да „уколико нека реч није препозната, додатно објашњење или визуелна подршка (најбоље филм или добра и јасна визуелна представа) значајно утиче на пораст разумевања и сарадње“. Истакнуто је и очекивање „да ће приближавање књиге корисницима пробудити занимање за читање и откривање нових медија и садржаја и да ће извршити позитиван утицај у смислу богаћења појмова, унутрашњег живота, погледа на свет и уопште квалитета живота наших корисника". На крају Извештаја дата је и препорука да величина групе буде ограничена на осам учесника. ${ }^{24}$

\section{Загрљај књиге: пролог}

Првом окупљању групе у Градској библиотеци, у јуну 2018, присуствовало је 12 заинтересованих у пратњи личних асистената. ${ }^{25}$ Разговор о њиховим читалачким интересовањима открио је да желе да читају о познатим музичарима и садржаје о музици, да их занимају „садашњост, прошлост, будућност, космос, звезде...", „стране књиге и стране песме“, „садржаји у вези са географијом, океанима и путописи“, „љубавне књиге“... Један члан се похвалио да се бави књиговезачким занатом, који је и завршио у школи. Сви су се бесплатно учланили у Библиотеку и добили своје чланске карте или продужили чланарину.

22 Испитивање је вршила Биљана Милошевић, дипл. дефектолог логопед, и у Извештају је истакла да „Тест читања базиран на тежини текста (Ђ. Костић, С. Владисављевић) утврђује способност читања текста по тежини од аутоматизованих речи (бројеви од 1 до 10, дани у недељи, делови дана, аутоматизоване фразе (поздрави, учтиво опхођење)), преко реченица, краћих и дужих текстова. Тестирање се прекида на степену на коме се праве учестале грешке. Тест има истраживачки и клинички карактер. Тродимензионални тест читања (адаптација стандардизованог теста француског ортофонисте Хелене Сах) намењен је особама које испољавају тешкоће у савладавању читања, проверава савладаност технике читања и разумевање садржаја текста. Оцењују се брзина читања, број неправилности и разумевање прочитаног текста према вербалним одговорима". - Градска

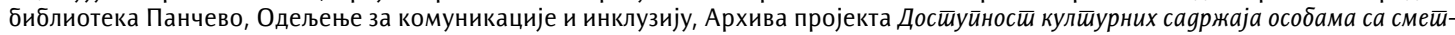
њама у развоју и иншеелекшеуалним шеешкоћама и Читалачког клуба Градске библиотеке Панчево, Биљана Милошевић, „Извештај о извршеној процени способности читања".

23 Нпр. аудио-књиге, ликовни, филмски приказ садржаја, драматизација, прилагођен ниво сложености реченице/текста, али на такав начин да остаје очуван смисао и квалитет оригинала, заједничко читање наглас, помагало у смислу ограничења визуелног поља које помаже да се поглед фокусира у жељеном правцу и елиминише ангажовање пажње на осталим речима/редовима текста током читања одређене речи/реда...

${ }_{24}$ Милошевић, „Извештај о извршеној процени способности читања“.

25 На састанку су били и чланови стручног тима за подршку, као и библиотекари са Дечјег одељења ГБП. На почетку сусрета, Марина Куриљ, главна координаторка Удружења „На пола пута“, изложила је циљеве и садржај пројекта. Затим су директор ГБП, Дејан Боснић и Горан Траиловић, аутор и координатор пројекта, говорили о Библиотеци и планираним активностима, а психолог Наташа Милојевић је са члановима групе разговарала о њиховим интересовањима. 
Наредни сусрет осмислила је и водила писац и библиотекар Милица Матијевић из Библиотеке „Димитрије Туцовић“ у Лазаревцу. Радионица „Загрљај књиге: пролог“ имала је улогу увода у предстојеће активности и сусрете са писцима. Нагласак је био на свим елементима живота који утичу на емотивни свет појединца (музика, боје, укуси, комуникација...). Централни и најинтересантнији део окупљања „Заједничка прича“, требало је да предочи колико је узбудљиво креирање приче, како машта утиче на ток радње и како се идеје преливају у ликове. Израђивани су лични портрети тако што су учесници лепили своје фотографије на велики хамер, а затим и исечене делове слика из часописа и исписивали речи које најбоље описују осећања и доживљаје током радионице. Сви млади су активно учествовали и нису се појавиле посебне потешкоће у разумевању садржаја радионице и у комуникацији. Појединим учесницима је била потребна подршка у изради портрета, лепљењу слика, записивању речи.

Три дана након састанка спроведен је кратак групни интервју са осам чланова клуба који су присуствовали радионици. ${ }^{26}$ Испитаници су одговарали на питања која су се односила на оно што им се допало и оно што им се није допало на радионици. Исказали су задовољство везано за активност грађења приче и друге врсте активности које подразумевају комуникацију. ${ }^{27}$ Истицали су незадовољство због помањкања правила у раду групе. Разговоре о узнемирујућим темама и личним причама такође су истакли као негативно, као и понашања која одступају од уобичајеног обрасца за место где се налазе. ${ }^{28}$ Интересантно је да су мишљења „друге стране“ била подељена: од изузетно повољног мишљења водитељке радионице ${ }^{29}$ и психолога, до одређених замерки дефектолога.

У Анализи резултата из „Евалуације“ издваја се закључак да уз јаснију структуру у вођењу, бољу информисаност учесника, темељнију припрему везану за све што се односи на специфичности учесника те одређене модификације и прилагођавања активности, радионица може са успехом да се примењује у раду са групом младих и одраслих са интелектуалним тешкоћама. Уз све наведено, може се користити као предактивност при увођењу младих у свет књижевности при формирању Читалачких клубова. ${ }^{30}$

У Извештају и „Детаљном приказу реализације радионице и коментарима“, друга стручна сарадница је, поред осталог, замерила да радионица није била структурирана ни просторно ни

\footnotetext{
${ }_{26}$ Радионици је присуствовало 11 чланова Клуба, али преосталих троје није испитано јер нису могли да присуствују интервјуу. -

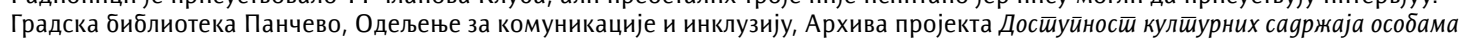

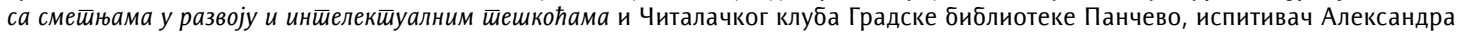
Јанић, стручни сарадник, „Евалуација“, Панчево, 29. 6. 2018.

27 Испитаници су одговорили да им се свиђа „што су сви причали о нечему и она Милица из Ваљева ми се свиђа и онај мали, нови Јоца“, „прича о бајкама, питања о животињама и природи“, „слике и папир и да напишемо шта нас означава и чини“, "смишљање приче и кад је Анђа почела причу о девојчици, па Сандра рекла за фрајера, супер ми то“, "свидело ми се да пишем, Сандра ми диктирала слова, оно да сам лепа“... - Градска библиотека Панчево, Одељење за комуникације и инклузију, Архива

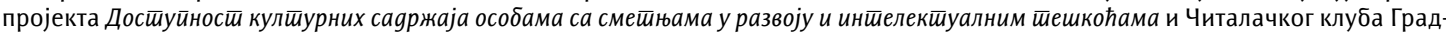
ске библиотеке Панчево, Јанић, „Евалуација“.

28 Замерили су да је било бучно, „велика галама“ („У библиотеци је тихо, а не бука“), сметало им је што су „сви говорили углас“, „галама, општи хаос, не зна се ко шта ради“, „драње и упадање другима у реч“, „како су лепили по мени неке слике“... Мањем броју испитаника је засметала "прича о крви и болу“ једог од учесника ( то ме јако потресло“) и „оно што су фарбали, прсти што се умачу“ („никад то нисам радила не волим“), као и то што „сви иду около и моја другарица стално, шетање“. Једна испитаница је рекла да "оно што је она жена причала није ми јасно“, а један испитаник је имао озбиљан приговор на садржај радионице; он сматра да је „свега ту било само не књижевности, било је више игре него књижевности и то за децу из основне школе“. - Јанић, „Евалуација“.

${ }^{29}$ С обзиром да се први пут сусрела са већином учесника, водитељка радионице је оценила да је радионица била веома успешна Група која је била присутна је веома активна, учесници су се са лакоћом укључивали у све замишљене процесе и били велика подршка једни другима. Неки од њих су веома надарени и учинили су ову радионицу изузетно интересантном. Она је настојала да их стимулише да што више самостално раде и резултат је био одличан. Сви су се укључивали на начин који је њима најближи. Уводни део је био замишљен као детаљније упознавање, али нажалост због неадекватног простора, није могао да буде реализован у складу са почетном идејом. Ипак, он је био одличан почетак за причу о речима и књигама која служи томе да ове младе људе охрабри и оснажи у настојањима да активно учествују у раду Читалачког клуба. - Градска библиотека Панчево

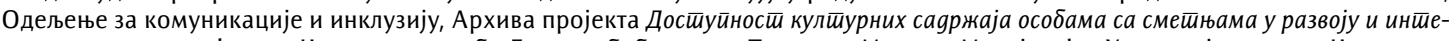
лекшиуалним шешкоћама и Читалачког клуба Градске библиотеке Панчево, Милица Матијевић, „У загрљају књиге - Читалачки клуб Градске библиотеке Панчево“.

30 Јанић, „Евалуација“.
} 
садржински и да није била ни у складу са узрастом и индивидуалним профилима лица којима је намењена. ${ }^{31}$ Психолог који је пратио радионицу је имао изузетно повољне утиске и, уз одређене замерке, позитивно оценио њен садржај и интерактивност, а пажњу усмерио на „препреке спонтаном току сурета“ (непоштовање стандардних правила групног рада). ${ }^{32}$

\section{Сусрети са песником}

Наредна два сусрета водио је песник Бранко Стевановић. Разговарало се о пореклу и значењу лексема, о „лепим речима“ и колико су оне значајне за леп живот. Учесници су сами предлагали теме за разговор: приче о вери, љубави, о томе које писмо умеју да читају. Читане су песме, разговарало се о томе која су то лепа осећања и стања те су побројана нека: маштовитост, радост, љубав, чежња-страст, пријатељство, искреност, поверење-поштовање, љубазност итд. ${ }^{33}$

На другом сусрету са песником, у форми активног разговора са њим, чланови клуба су покушали да представе лепе речи које су поменуте на претходном састанку. Свако је добио задатак да лексему која је ишла уз њега представи на листу папира у форми којој жели. Представљане су: маштовитост, поверење, поштовање, племенитост, искреност, срећа, симпатичност, љубав, чежња, свесност, и о њима се живо дискутовало. На самом крају Бранко Стевановић је прочитао песму на тему свесности, која је такође коментарисана.

Последњи јулски састанак Клуба, пред летње ферије (коме су присуствовали скоро сви чланови), одржан је у башти кафеа Културног центра уз кафу и освежење, а без „дневног реда“. Том приликом су сви у оближњој књижари изабрали „своју“ књигу коју су добили на поклон уз договор да је најесен представе другима. ${ }^{34}$

\section{Јесен Читалачког клуба}

На првим јесењим састанцима разговарано је о летњем распусту и размотрене су идеје и активности до краја године. „Стари“ чланови су упознали нове са општом идејом и досадашњим радом Клуба. Утврђена су правила понашања и комуникације, причало се о томе да ли су и шта читали у протеклом периоду, о летњим путовањима и доживљајима. Подсетили су се

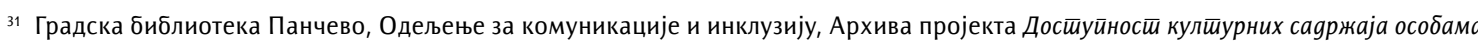

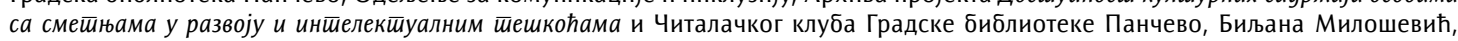
"Извештај и Детаљан приказ реализације радионице и коментари".

32 Градска библиотека Панчево, Одељење за комуникације и инклузију, Архива пројекта Досйуӣносй кулйурних саgржаја особа-

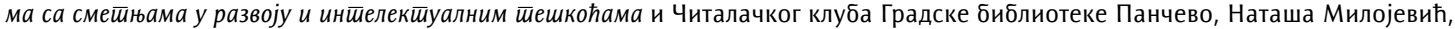
„Друго окупљање групе".

33 Поново су групно испитивани утисци учесника и они су до једног били позитивни („Лепо је то место за читање и писање, баш оно што ја волим. Онај песник што нам је читао песме је за сваку похвалу. Све ми се допало нема нешто што замерам“; “Сидело ми се како је причао о понашању, о вери, како полако прича. Како да будемо паметни и љубазни“; „Допала ми се прича на тему како трговац треба да се понаша према муштеријама, како им се љубазно и лепим речима треба обраћати. Допало ми се кад смо осмишљавали лепе речи за песму коју ћемо написати“; „Најлепше што сам могла да читам песму, све нам је објаснио“; "Допало ми се што сам упознао новог писца, супер човек“). Једном испитанику се није допала прича о животињама („Не волим животиње јер могу да поједу човека за доручак“), а осталима „кад сви причају истовремено“.

Закључак стручног тима, после првог сусрета са песником, био је да су присутни активно учествовали у раду и да су општи утисци позитивни, а да су активности које је спроводио писац оставиле добар утисак на учеснике. И даље се провлачи проблем непоштовања времена када ко говори и неких општих правила понашања у раду групе. Степен учешћа појединаца је био изузетно висок, док су неки пасивно посматрали целу радоницу.

Учесници који су приликом прелиминарне процене имали најбоље резултате су својим луцидним објашњенима у великој мери подигли квалитет функционисања групе и изнедрили пуно лепих закључака и објашњења. Остатак групе је дао свој допринос раду у складу са приликом коју је добио и личним капацитетима. Утисак је ипак да су сви задовољано напустили састанак. -Јанић, „Евалуација“.

34 Члановима Клуба није дата нека посебна сугестија приликом избора књига. У складу са својим интересовањима, изабрали

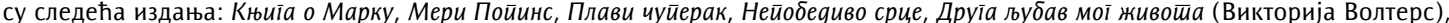

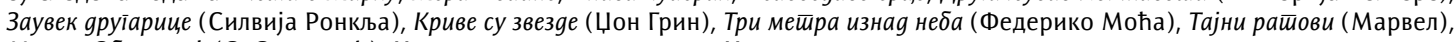
Милош Обреновић (С. Станишић), Нлусировани рокенрол воgии, Неколико минуйа масаже... 
лепих речи и тога да оне описују и осећања о којима се разговарало на састанцима које су водили Милица Матијевић и Бранко Стевановић.

По први пут су два члана, уз поезију Мирослава Антића и других песника, читала своје песме, а онда је вођен разговор о томе да ли им се оне допадају и која осећања буде. Некако су се јавиле приче о Богу и космосу, што једног члана Клуба посебно занима, тако да је тражена литература о овим темама и разговарано о њима. Како је предстојао сусрет са глумцима у октобру, било је потребно утврдити текстове које би учесници волели да им говоре том приликом. Предложили су песме Мирослава Антића, своје песме, „Песму над песмама“, "Santa Maria della Salute" Лазе Костића, Нушићеве драме...

А онда су дошли глумци и уследили су најзанимљивији и најдинамичнији састанци. У ствари, „на сцени“ је била само глумица Боба Латиновић. Она се представила и најавила да ће бити на неколико наредних сусрета и, у односу на интересовања младих, водити активности које су у вези са књижевношћу, односно књижевним текстовима. Затим су се представили чланови Клуба, рекли где и са киме живе, ко им помаже, шта воле, којим спортовима се баве, а неки су се похвалили својим глумачким стажом и талентима. ${ }^{35}$

Разговарало се о томе шта би чланови волели да раде на будућим сусретима и дошло се до тога да би могли да креирају позоришну представу. Ипак, на наредном састанку је одлучено да сниме краћи играни филм. Они су сами, или уз подстицај, предлагали „приче“ на основу којих је касније рађен сценарио и разговарали о ликовима које ће тумачити. ${ }^{36}$

После једномесечних припрема, започело је пробно снимање, затим је анализиран немонтирани снимак и дате улоге члановима који нису присуствовали претходним сусретима. Читав сценарио, укључујући и поделу улога и згодан заплет су осмислили сами чланови Клуба. Асистенти, режисер и сниматељ Владимир Кајловиц и глумица Боба Латиновић су пружили техничку и саветодавну помоћ. Филм је назван Љубав у библиошеци ${ }^{37}$ и приказиван је на окупљањима у новембру месецу. Убрзо је постављен на Јутјбб са линковима на друштвеним мрежама, тако да су и други заинтересовани могли да га виде. Свима се допао, а и реакције самих „глумаца“, који су у одјавној шпици потписани својим надимцима, биле су изузетно позитивне.

\section{Епилог}

Одељење за комуникације и инклузију Градске библиотеке Панчево је, у сарадњи са Пан-

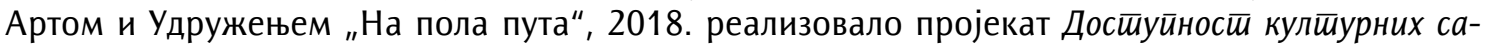

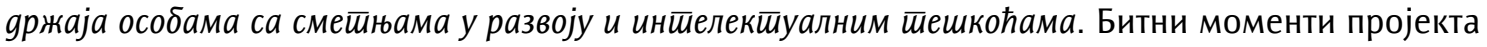
су документовани, прикупљена је обимна текстуална, фото и видео-документација, стечено богато искуство, проверене неке почетне хипотезе и креиран могући модел рада са овом

\footnotetext{
35 „Бавио сам се глумом, глумио сам у представама са 14 година, пишем песме“; „Певам у хору у Долову, селу где живим, волим да фотографишем и рачунарство“; „Волим да слушам музику, мало свирам гитару, мало хармонику; у слободно време правим ручно књиге, волим да играм игрице на компјутеру и гледам филмове, радим декупаж, био сам учесник у филмовима о Удружењу и самозаступању“; "Пишем песме и наступала сам са својим песмама као песник на данима поезије на Звездари, учествовала сам у филмовима о организацији Асоцијација за промоцију инклузије, имам брата који прави ТВ емисије“; „Волим пецање и идем у фитнес у клуб СМС, играм фудбал са млађим братом и волим да се дружим“; „Радим од накита до декупажа волим куце и волонтирам у удружењу за напуштене животиње, идем на вајање код Иване Крумес“; "Идем на музичке радионице; перем суђе, пеглам, перем прозоре, волим масажу“; „Волим возове и волео бих да научим сито-штампу и нађем стално занимање"....

36 Двоје учесника је себе у филму видело као заљубљени пар (да седе и држе се за руке или се прошетају/улазе у Библиотеку загрљени). На ову идеју реаговала је друга учесница која је изјавила да ће онда она бити девојка која ће седети са једним од учесника, нешто ће као учити, читати и коментарисати заљубљени пар. Предложила је и шта да изговори у тој сцени: „Л. у праву си, идемо, чекај да понесем књиге и свеске.“... Договорено је да текст који би требало да изговори један од учесника буде на папиру који ће можда показати (као у немим филмовима), или ће текст научити напамет јер има тешкоћа са читањем. Изразио је жељу да има шешир и кравату у филму.

37 Доступан на https://www.youtube.com/watch?v=A_iwpil-Cy4
} 
специфичном популацијом. Окупљен је квалитетан стручни тим и формиран Читалачки клуб. На основу резултата испитивања, реакција, мишљења и личног увида аутора, може се закључити да је рад Клуба био успешан и да су чланови уживали у активностима и дружењу. ${ }^{38}$

Читалачки клуб је окупио двадесетак особа са сметњама у развоју и интелектуалним тешкоћама и од почетка је било јасно да уобичајена форма рада оваквог програма мора да буде њима прилагођена. Зато је пружена лична асистенција, а активности су пратили и усмеравали чланови стручног тима састављеног од дефектолога, педагога, психолога и библиотекара. Формирању Клуба је претходило решавање организационих, техничких и финансијских питања и припреме су трајале више месеци. Испоставило се да у Србији и окружењу готово да и није било сродних програма ни литературе који би помогли аутору и организаторима програма. Схватили су да улазе у својеврстан експеримент са много непознаница и могли су да се ослоне само на своју креативност, искуство и стручност ангажованих сарадника.

Циљ пројекта, да се помогне особама укљученим у њега да читање доживе као пријатну активност и развију љубав према књизи, начелно је остварен. Оне су са великим ентузијазмом прихватиле учешће у раду Клуба и пружиле свој креативни допринос у реализованим активностима. Реакције, иницијативе, интересовања и ставови учесника често су умели да изненаде модераторе, стручне сараднике и аутора пројекта. Били су слободни да изразе своја размишљања и интересовања, певају, глуме и говоре своју поезију. Потврђена је оправданост мултидисциплинарног приступа и ангажовање стручњака различитих профила: од посредника између писаног текста (драмских уметника, писаца...) и њих, преко личних асистената, до специјалиста (логопеда, дефектолога, психолога...). То је, са једне стране, дало динамику активностима, а са друге пружило сигурност и неопходну помоћ аутору и координатору пројекта.

Тешкоће које су се јавиле односе се на класичне проблеме групног рада. Оне су релативно лако отклоњене. Уочен је мањак концентрације код једног броја чланова Клуба и недовољна способност читања и разумевања прочитаног, или чак немогућност препознавања графема, читање речи и аутоматских секвенци (у већој или мањој мери присутно код половине чланова). Психолози у тиму су констатовали да је реч о очекиваним и уобичајеним „препрекама“ које су организатори и водитељи састанака, углавном, са успехом превазилазили прилагођавајући активности пројекта могућностима, односно ограничењима учесника.

Пола године активног рада Клуба је мало времена да би се доносили далекосежни закључци. Може се, ипак, рећи да су све групне активности успешно реализоване. Љубав према књизи постоји код ових младих људи и она није упитна. Проблем је да они који имају озбиљне тешкоће са концентрацијом и препознавањем графема читање (без посредника) доживе као пријатну активност.

Поставља се и питање сврсисходности ангажовања великог броја стручњака на пројекту за релативно мали број особа којима је он био намењен, али библиотеке су, као што је истакнуто на почетку текста, својом мисијом и домаћим и међународним актима, у обавези да развијају потребне сервисе за њих. Реч је о цивилизацијској тековини бриге за припаднике „рањиве популације ${ }^{39}$ Нскуство говори да овакав клуб може да се реализује (са ограниченим

\footnotetext{
38 Без посебне маркетиншке кампање и пре са жељом да се рад Клуба, из више разлога, одвија даље од очију шире јавности, он је промовисан на локалном и националном нивоу на иницијативу представника медија (извештај са једне од првих радионица приказан је и у Дневнику РТС). Полусатни играни филм Љубав у библиошеци је скренуо додатну пажњу на његов рад, а документарни филм који прати све битне моменте пројекта сведочи о начину рада и његовим активностима. Поједине библиотеке и организације цивилног сектора су изразиле озбиљно интересовање за сарадњу са ГБП и Клубом.

39 Идеја сензибилисања већег броја библиотекара за рад и развој сервиса за особе са сметњама у развоју и интелектуалним тешкоћама, такође није остварена. Један од разлога може бити исувише кратак временски период у коме се пројекат реализовао, недовољна информисаност и недовољна иницијатива организатора да их укључи у пројекат. Други разлози који се тичу мотивисања и спремности за овакво ангажовање су ван утицаја аутора и организатора сличних програма и налазе се у окружењу у коме библиотекари делују.
} 
претензијама и дометима) и са много мање ангажованих спољних сарадника и стручњака, по моделу класичног читалачког клуба где је централна особа медијатор који организује и води састанке. Помоћ личних асистената током трајања састанка није неопходна. ${ }^{40}$ „Посредници“, глумци и писци су добродошли, али клуб може да функционише и без њих. За додатне активности, попут реализације позоришне представе или снимања филма су, наравно, потребни квалификовани сарадници.

Искуство стечено у једногодишњем раду дало је добру основу за план активности за наредни период (листе књига, позоришна представа, ауторска дела, профили на друштвеним мрежама, веб-презентација итд.). Све ово, уз велики ентузијазам и жељу свих учесника пројекта да се активности наставе, било је гаранција ауторима и организаторима да ће Министарство културе и Град Панчево наставити да суфинансирају његов рад. Захтеви за даљу подршку, уз богату текстуалну, фото и видео-документацију послати су на републичке и градске конкурсе, али, на велико разочарање и из непознатих разлога, ова подршка је изостала. То је био велики финансијски, а још више морални ударац ауторима и организаторима, на који је требало одговорити додатним ентузијазмом и ангажовањем. Први део 2019. године је протекао у плановима и ишчекивању резултата конкурса, ${ }^{41}$ а после летње паузе због других обавеза, они нису били у могућности да сами, без одобреног буџета за пројекат, реализују планиране активности. Проглашена епидемија корона вируса и економска ситуација у земљи су ове године одложиле наставак рада и окупљања чланова Клуба.

Аутор пројекта се нада да ће, у наредном периоду, они који брину о културној политици и

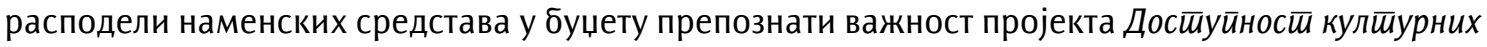

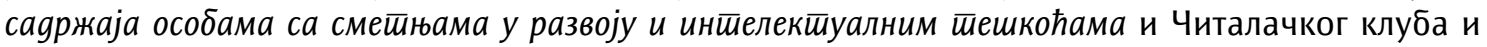
омогућити организаторима да наставе започете активности са његовим члановима.

\section{Литература и извори:}

1. Biblioteka grada Beograda. „Čitalački klub 'Čitanja i odgovori'“. Preuzeto 20. 5. 2020. https://www. bgb.rs/index.php/zemun/1259-2018-04-20-10-12-10.

2. Danić Grbić, Biljana. „Uloga biblioteka kao agensa socijalizacije dece i omladine sa posebnim potrebama". U Deca i biblioteke: zbornik radova sa međunarodnog naučnog skupa održanog u Beogradu od 5. do 9. oktobra 2005, 655-665. Beograd: Filološki fakultet Univerziteta; Bibliotekarsko društvo Srbije, 2006.

3. Dejns-Džouns, Kortni,prir. Unapređivanje bibliotečkih usluga za osobe s invaliditetom (Improving Library Services to People with Disabilities). Prevela Dragana Milunović. Beograd: Narodna biblioteka Srbije, 2009.

4. Gradska biblioteka Pančevo. Arhiva. Dečija biblioteka je otvorena 1. maja 1956. Dopis upravnika GBP, Đorđa Vlajića Narodnom odboru opštine Pančevo, Odeljenju za prosvetu i kulturu, br. 397, od 20. 12. 1957.

5. Gradska biblioteka Pančevo, Odeljenje za komunikacije i inkluziju. Arhiva projekta Dostupnost kulturnih sadržaja osobama sa smetnjama u razvoju i intelektualnim teškoćama i Čitalačkog kluba Gradske biblioteke Pančevo.

\footnotetext{
40 Одређена подршка спољних сарадника и стручњака је ипак потребна, можда не толико око процене тока састанака од којих зависи „даља модификација клупских садржаја“, колико у почетној фази одабира чланова. То "фазно ангажовање“ је посебно драгоцено на почетку. Касније, када се установе процедуре и рад Клуба заживи, може и без стручних сарадника. Личност медијатора и његове компетенције су од велике важности и подршка личног асистента на окупљањима је такође драгоцена ако он не познаје специфичности чланова оваквог клуба. Александра Јанић, e-таil порука аутору, јун 2018.

41 Ово је још један пример на коме се очитује нетранспарентност рада комисија надлежних тела у култури и слабости једногодишњег финансирања пројеката чији резултати и одобрена средства буду доступни тек средином године. Тешко је објаснити зашто исти пројекат није подржан на конкурсу Министарства 2017. године, па финансиран 2018, а иако је више него успешно реализован, није подржан његов наставак 2019. године.
} 
6. Gradska biblioteka Pančevo, Odeljenje za komunikacije i inkluziju. Arhiva projekta Dostupnost kulturnih sadržaja osobama sa smetnjama u razvoju i intelektualnim teškoćama i Čitalačkog kluba Gradske biblioteke Pančevo. Ispitivač Aleksandra Janić, stručni saradnik. „Evaluacija“, Pančevo, 29. 6. 2018.

7. Gradska biblioteka Pančevo, Odeljenje za komunikacije i inkluziju. Arhiva projekta Dostupnost kulturnih sadržaja osobama sa smetnjama u razvoju i intelektualnim teškoćama i Čitalačkog kluba Gradske biblioteke Pančevo. Matijević, Milica. „U zagrljaju knjige - Čitalački klub Gradske biblioteke Pančevo".

8. Gradska biblioteka Pančevo, Odeljenje za komunikacije i inkluziju. Arhiva projekta Dostupnost kulturnih sadržaja osobama sa smetnjama u razvoju i intelektualnim teškoćama i Čitalačkog kluba Gradske biblioteke Pančevo. Milojević Nataša. „Drugo okupljanje grupe".

9. Gradska biblioteka Pančevo, Odeljenje za komunikacije i inkluziju. Arhiva projekta Dostupnost kulturnih sadržaja osobama sa smetnjama u razvoju i intelektualnim teškoćama i Čitalačkog kluba Gradske biblioteke Pančevo. Milošević, Biljana. „Izveštaj i Detaljan prikaz realizacije radionice i komentari“.

10. Gradska biblioteka Pančevo, Odeljenje za komunikacije i inkluziju. Arhiva projekta Dostupnost kulturnih sadržaja osobama sa smetnjama u razvoju i intelektualnim teškoćama i Čitalačkog kluba Gradske biblioteke Pančevo. Milošević, Biljana. „Izveštaj o izvršenoj proceni sposobnosti čitanja“.

11. Gradska biblioteka u Novom Sadu. Preuzeto 12. 5. 2020. https://www.gbns.rs/index. php?option=com_content\&view=article\&id=974:04102019-citalacki-klub\&catid=40\&ltemid=205.

12. Gradska knjižnica i čitaonica Pula. „Klub ljubitelja čitanja KLjuČ“. Preuzeto 20. 5. 2020. https://gkcpula.hr/hr/proba-broj-cetiri/k/.

13. IFLA/UNESCO. Manifest za javne biblioteke. Preuzeto 14. 8. 2019. https://www.ifla.org/files/assets/public-libraries/publications/PL-manifesto/pl-manifesto-sr.pdf.

14. Knjižnice grada Zagreba, Čitalački klub. „,Mojih sat vremena čitanja' u Knjižnici Savski gaj (Zagreb)“. Preuzeto 15. 3. 2020. http://www.kgz.hr/hr/knjiznica-sirom-otvorenih-vrata-5993/citalacki-klub/6337.

15. Međunarodna federacija bibliotekarskih udruženja i institucija, IFLA, UNESCO. Međunarodni bibliotečki manifesti. Priređivači i redaktori prevoda Vesna Injac i Dragana Milunović, urednik Vesna Crnogorac. Beograd: Bibliotekarsko društvo Srbije, 2014. Dostupno i na: http://nub.rs/fileadmin/dokumenti/ostali_dokumenti/Medjunarodni-bibliotecki-manifesti.pdf.

16. Milunović, Dragana. Biblioteke za hendikepirane. Beograd: Zadužbina Andrejević, 2006.

17. Milunović, Dragana. „Hendikepirana deca kao korisnici bibliotečkih usluga“. U Deca i biblioteke: zbornik radova sa međunarodnog naučnog skupa održanog u Beogradu od 5. do 9. oktobra 2005, 501-507. Beograd: Filološki fakultet Univerziteta; Bibliotekarsko društvo Srbije, 2006.

18. Milunović, Dragana. Ka korisniku sa invaliditetom: 100 pitanja i 100 odgovora u vezi sa formiranjem i razvojem bibliotečkih usluga za osobe sa invaliditetom. Beograd: Narodna biblioteka Srbije, 2012.

19. Milunović, Dragana. Tekst u govor: principi alternativnih metoda čitanja kod osoba sa invaliditetom. Beograd: Narodna biblioteka Srbije, 2017.

20. Narodna biblioteka „Veljko Petrović“ Bačka Palanka. „Čitalački klub“. Preuzeto 20. 5. 2020. http:// www.bibliotekabackapalanka.com/index.php/dogadjanja/vesti/923-klub.

21. Sabolović-Krajina, Dijana, Ljiljana Vugrinec i Danijela Petrić. „Knjižnična usluga za slijepe i slabovidne u Knjižnici i čitaonici 'Fran Galović' Koprivnica: od projekta do implementacije“. Vjesnik bibliotekara Hrvatske God 53, br. 2 (2010): 76-92.

22. Tarabić, Božidar Nikša i Patricia Tomac. „Intelektualne teškoće - dijagnostika i klasifikacija“. Gyrus 3 (2014): 130-133.

23. Trailović, Goran. „Đorđe Vlajić, upravnik Gradske biblioteke Pančevo (1955-1973)“. U Biblioteke i identitet 2: zbornik radova sa naučnog skupa održanog 24. i 25. maja 2019. godine u Pančevu, glavni urednik Gordana Stokić Simončić, odgovorni urednik Goran Trailović, 96-106. Pančevo: Gradska biblioteka, 2019. 
Траиловић Г. „Читалачки клуб за особе са интелектуалним тешкоћама“, 24-36

\section{Reading Club for Persons with Intellectual Disabilities}

\section{Summary}

At the beginning of 2018, the Department of Communication and Inclusion of the City Library of Pančevo initiated the establishment of a reading club, the first of its kind since the establishment of this institution. The club was intended for young people with difficulties in the perception of literary texts, and was successfully implemented within the project Accessibility of Cultural Contents for Persons with Developmental and Intellectual Disabilities. It was organized in partnership with the Center for Culture and Ecology PanArt and the Halfway Association, with the support of the Society for Helping Mentally Underdeveloped Persons. The Ministry of Culture and Information of the Republic of Serbia and the City Administration of Pančevo financed the basic expenses of the project, and the City Library of Pančevo participated with additional funds from its own budget. The project gathered about twenty young people, and their work was monitored and directed by the professional team made of six members (special educators, pedagogues, psychologists, librarians).

The action of establishing the club was preceded by settling a number of organizational, technical and financial issues, so the preparations lasted for several months. The first activities started in May. Some twenty official gatherings of the club members were held, as well as a number of unofficial ones, including visits to exhibitions, going to the theater and a tour of the Book Fair in Belgrade. Gatherings were held every Tuesday 6:00 - 8:00 PM in the small reading room of the library. The evaluation of the project was continuous, with a regular report after each gathering and conclusions on the basis of which plans were made for the next period. Almost all important segments of the work within the club were recorded and documented on videos which are kept in the archives of the club and the project at the Department of Communications and Inclusion of CLP, together with the other relevant documentation. The organizers did not plan to go public before the end of the project since it was the first and the only one of its kind in Serbia, and therefore followed by great unknowns. However, at the initiative of media representatives from Pančevo and other cities, the club was presented at both local and national levels. Thanks primarily to the film Love in the Library, which was shot based on a script written by the club members themselves, some libraries and civil society organizations have expressed serious interest in this project and cooperation with the City Library of Pančevo and the club.

Although the project was realized successfully, and all participants expressed great readiness to continue working on it, the Ministry of Culture and Information of the Republic of Serbia and the City of Pančevo refused to help it financially in 2019 (2019 call for project proposals), which greatly discouraged the organizers. Even though there was no lack of enthusiasm, various professional obligations prevented them from dealing with fundraising and the work of the club, so its activities ceased.

Keywords: reading club, accessibility of cultural content, persons with developmental disabilities, persons with intellectual disabilities, perception of literary text, City Library of Pančevo (CLP), Department of Communication and Inclusion, Center for Culture and Ecology PanArt, Halfway Association, Society for Helping Mentally Underdeveloped Persons, professional associates, individual reader's card 


\section{(ब) $(\Theta \Theta$}

Читалачки клуб за особе са интелектуалним тешкоћама by Горан Траиловић is licensed under a Creative Commons Attribution-NonCommercial-NoDerivatives 4.0 International License. 